\title{
Evde Sağlık Hizmetlerinde İnformal Bakım Verenlerin Bilgi ve Beceri Düzeyinin Belirlenmesi
}

\section{Determination of the Level of Knowledge and Skill of Informal Caregivers in Home Health Care}

\author{
${ }^{1}$ Özden GÜDÜK, ${ }^{2}$ Özlem GÜDÜK, ${ }^{3}$ Yaşar SERTBAȘ \\ ${ }^{1}$ Yüksek İhtisas Üniversitesi, ANKARA \\ 2 İstanbul Sağlık Müdürlüğ̈̈, İSTANBUL \\ ${ }^{3}$ İstanbul Sağlık Müdürlüğü, Kamu Hastaneleri Hizmetleri Başkanlığı-2, İSTANBUL
}

Özden Güdük: https://orcid.org/0000-0002-2268-0428

Özlem Güdük: https://orcid.org/0000-0003-0929-1302

Yaşar Sertbaş: https://orcid.org/0000-0002-9685-4486

\section{ÖZ}

Amaç: Evde sağlık hizmetlerinden yararlanan hastaların yakınlarının bilgi ve beceri durumunun değerlendirilmesidir.

Materyal ve Metot: 2019 yılı Ocak-Mart ayları arasında ziyaret edilen 616 hastanın yakınına ulaşılmıştır. Araştırmacılar tarafından literatür taraması ile oluşturulan anket uygulanmıştır. Analizlerde SPSS Statistics 22 programı kullanılmıștır.

Bulgular: Bakım verenlerin \% 74,2'si 34-65 yaş grubunda ve $\% 84,4$ 'ü kadındır. Katılımcıların \%63'ü hastanın birinci derece akrabası olup, \%44,9'u ilköğretim okulu ve altında eğitim seviyesine sahiptir. Bakım verenlerin \%85' hasta bakımı konusunda eğitim almadığını ifade etmiştir. Hastaların \%46,5'inin tam bağımlı olduğu ve \%20,8'inde dekübit ülseri geliştiği saptanmıştır. Katılımcıların yarısı $(\% 50,5) 3$ yıldan daha az süredir bakım vermekte, \% 69,2'si gün içinde 17-24 saat arası bakım görevini üstlenmektedir. Bakım verenin bir ay içerisinde hasta bakımı yapmaksızın kendisine ayırdığı gün ortalaması 2,24 $( \pm 4,77)^{\prime}$ bulunmuştur. Bakım verenlerin tıbbi cihazların kullanımı, bakımı, temizliği ve arızalanması durumunda yapılacaklar konusunda bilgilerinin az olduğu görülmüștür. Hastanın uyması gereken diyeti, kullandığı ilaçlar ve hijyen bakımı ile ilgili ifadelerin en yüksek bilgi düzeyine sahip olduğu görülmüştür. Bakım verenin eğitim seviyesi, yașı, hastaya bakım verdiği süre ve daha önce başka bir hastaya bakım vermiş olma durumunun sahip olduğu bilgi/beceri üzerine etkili olduğu bulunmuştur.

Sonuç: Hasta yakınlarının bilgi ve beceri düzeyinin yükseltilmesi, hastanın alacağı bakımın kalitesini yükseltecek ve hastayı olumsuz sağlık koşullarından koruyacaktır.

Anahtar Kelimeler: Evde sağlık hizmeti, hasta, informal bakicilar

\begin{abstract}
Objective: The aim of this study to evaluate the knowledge and skills of caregivers of patients who received service from home health care.

Materials and Methods: A survey was applied to the caregivers of 616 patients between January and March 2019. SPSS 22.0 program was used for analysis.

Results: $74.2 \%$ of the caregivers were between $34-65$ age and $84.4 \%$ were women. $63 \%$ were first degree relatives of the patient, $44.9 \%$ had primary school and below education level and $85 \%$ stated they hadn't receive any training for patient care. $46.5 \%$ of the patients were fully dependent and $20.8 \%$ had decubitus. Half of the participants $(50.5 \%)$ were providing care for less than 3 years, $69.2 \%$ took care of 17-24 hours a day. The average number of days allocated by the caregiver without providing patient care in a month is $2.24( \pm 4.77)$. Caregivers had little knowledge about using medical devices. Patients diet, medications and hygiene care had the highest level of knowledge of caregivers. Education level of the caregivers, duration of care, prior experience of caregiving had an effect on their knowledge/skills.

Conclusion: Increasing the knowledge and skills of the relatives of patients will increase the quality of care and protect the patient from adverse health conditions.

Keywords: Home health care, informal caregivers, patient
\end{abstract}

Sorumlu Yazar / Corresponding Author:

Özden Güdük

Yüksek İhtisas Üniversitesi, Oğuzlar Mah. 1375. Sokak Balgat

ANKARA

Tel: 05327180938

E-mail: ozdenguduk@hotmail.com

\section{Yayın Bilgisi / Article Info:}

Gönderi Tarihi/ Received: 29/05/2020

Kabul Tarihi/ Accepted: 16/10/2020

Online Yayın Tarihi/ Published: 30/12/2020

Atıf / Cited: Güdük Ö, ve ark. Evde Sağlık Hizmetlerinde İnformal Bakım Verenlerin Bilgi ve Beceri Düzeyinin Belirlenmesi. Online Türk Să̆llk Bilimleri Dergisi 2020;5(4):648-660. doi: 10.26453/otjhs.744878 


\section{GÍRIŞ}

İnsan ömrünün uzaması ve düşük doğum hızı nedeniyle toplam nüfus içinde yaşlı nüfus oranı artış göstermektedir. OECD ülkelerinin üçte ikisinde 2050 y1lına kadar nüfusun en az dörtte birinin 65 'den daha yaşlı olacağ ${ }_{1}$ öngörülmektedir. ${ }^{1}$ Türkiye İstatistik Kurumu'na (TÜİK) göre ülkemizde ortalama yaşam süresi dünya ortalamas1nın üzerindedir. ${ }^{2}$

“İstatistiklerle Yaşlılar 2018” raporunda, ülkemizde yaşlı nüfusunun her geçen yıl artış gösterdiği ve göstermeye devam edeceği ifade edilmektedir. $^{3}$

Yaşlı nüfusun artması toplumun sağlık ihtiyacını da değiştirmektedir. Eskiden bulaşıcı hastalıklar en büyük sağl1k sorunları iken; günümüzde kronik hastalıklar, diyabet, obezite, kanser gibi bulaŞıcı olmayan hastalıklar ölümlerin ve sağlık harcamalarının başlıca sebepleridir. Hastane hizmetlerindeki maliyetlerin artması, sağlıktaki insan gücünün yetersizliği, hastaların kendi ortamlarında hizmet alma talepleri gibi nedenler sağllk hizmetlerinin evde sunulmasını artırmaktadır. ${ }^{4}$ Ülkemizde 2010 yılından itibaren Sağlık Bakanlığı'na bağlı hastanelerde evde sağlık hizmetleri yürütülmekte ve takip edilen hasta sayısı hızla artmaktadir. $^{5}$

Yaşlılarda, hastalıklara bağlı duyusal ve bilişsel değişiklikler sıklıkla görülmektedir. Farklı sağlık sorunları nedeniyle özbakım becerisi azalan yaşlıların sağlık ve bakım hizmetlerinin sürdürülebilmesi için destek almaları gerekmektedir. $\mathrm{Bu}$ bakım desteği birden fazla hizmetin bir arada sunulmasını gerektirmektedir. ${ }^{6}$

Evde sağlık hizmetleri genellikle yaşlılara verilmesi nedeniyle sıklıkla geriatrik hizmetlerle ilişkilendirilmektedir. Pek çok çalışma evde sağlık hizmeti kullanıcılarının çoğunluğunun 60 yaş üzeri hastalardan oluştuğunu göstermektedir. ${ }^{7}$

${ }^{11}$ Ancak sadece yaşlılık ve yaşlılığa bağlı hastalıklar nedeniyle değil, aynı zamanda fiziksel ve mental yetersizlik nedeniyle de bireylerin uzun dönemli bakıma ihtiyacı doğmaktadır. ${ }^{4}$

Evde sağlık hizmetleri formal bakıcılar (sağlık profesyonelleri), informal bakıcılar (aile ve arkadaşlar) ve kişilerin kendi kendilerine bakım sağlamaları şeklinde farklı kişiler tarafından sağlanabilmektedir. ${ }^{12,13}$ Çalışmalar bakım gerektiren hastaların bakımını, hastanın bir yakını veya arkadaşının üstlendiğini ve bu kişilerin çoğunlukla kadın olduğunu göstermektedir. ${ }^{14}$ Kurumsal hizmetlerin giderek artmasına karşın; evde bakımın büyük çoğunlukla aile bireyleri tarafindan verilmesinin sebepleri sadece ekonomik nedenlerden değil aynı zamanda sosyal ve kültürel nedenler ve evde bakımın "ailenin temel görevi" olarak görülmesinden kaynaklanmaktadır. ${ }^{15}$

Hastalarının günlük yaşam aktivitelerini sürdürmede sorunlar yaşamaları nedeniyle evde bakım hizmetlerinin organizasyonuna gereksinim duyulmaktadır. Hastaların farklı ve çeşitli ihtiyaçlarına cevap verebilmek için bakım verenlerin yetkin, bilgili ve becerili olması önemlidir.

Çalışmada evde sağlık hizmetlerinden yararlanan hastaların yakınlarının bilgi ve beceri durumunun değerlendirilmesi amaçlanmıştır.

\section{MATERYAL VE METOT}

İstanbul Üsküdar Devlet Hastanesi Evde Sağlık Hizmetleri Koordinasyon Merkezi'nden hizmet alan hastalara bakım verenlerin tümü evren olarak alınmıştır. Çalışmanın yapıldığı tarihte Merkeze kayıtlı 15.130 hasta bulunmaktadır. \%95 güven aralığı ve $\% 5$ hata payı ile hesaplama yapıldığında örneklem büyüklüğü en az 384 olarak bulunmuştur. Çalışma öncesi SBÜ Fatih Sultan Mehmet Eğitim ve Araştırma Hastanesi Etik Kurulu'ndan onay alınmıştır (Tarih: 28/03/2019, karar no: 2019/6). Çalışma, uluslararası deklarasyon, kılavuz vb. uygun olarak gerçekleştirilmiştir.

Araştırmacılar tarafından literatür taraması ile oluşturulan anket, evde sağlık çalışanları tarafından çalışmaya gönüllü olarak katılmayı kabul eden 616 hasta yakınına 2019 yılı Ocak-Mart ayları arasında uygulanmıştır. Anket uygulayan kişiler tarafından katılımcılar çalışma hakkında bilgilendirilmiş ve yazılı onamları alınmıştır. Anket, hastaya ait sosyo-demografik özellikler ve bakım verenin bilgi/becerisini değerlendiren 24 adet açık uçlu ve çoktan seçmeli soru ile 7 adet likert tipi ifadeden oluşmaktadır.

İstatistiksel analizler için SPSS Statistics 22 programı kullanılmıştır. Parametrelerin normal dağılıma uygunluğu ShapiroWilks testi ile değerlendirilmiştir. Tanımlayıcı istatistiksel metodların (ortalama, standart sapma, frekans) yanı sıra niceliksel verilerin karşılaştırılmasında normal dağılım göstermeyen parametrelerin karşılaştırmalarında Kruskal Wallis testi ve Mann Whitney U test kullanılmıştır. Anlamlılık $\mathrm{p}<0.05$ düzeyinde değerlendirilmiştir. 


\section{BULGULAR}

Bakım veren kişilerin \%74,2'si 35-64 yaş arasındadır ve \%84,4'ü kadınlardan oluşmaktadır. Hasta ile yakınlığı açısından değerlendirildiğinde \% 63'ünün birinci derece akrabası olduğu tespit edilmiştir. Eğitim durumları açısından en kalabalık grubun \%31,6 ile ilkokul mezunları (5 y1llık) olduğu görülmüştür. Katılımcıların \%86,5'i hasta bakımı dışında bir işte çalışmadığını \%14,1'i evde hasta ve bakım veren dışında başka kimseyle yaşamadığını ifade etmiştir (Tablo 1).

Hastaya bakım verenlerin \%20,3'ü hastaya bir yıldan az süredir bakım vermektedir ve $\% 69,2$ 'si gün içinde 17-24 saat arasında hasta bakımını üstlenmektedir.

Anket uygulanan kişilerin \%77,3’ü daha önce başka bir hastaya bakım vermemiş ve \%85'i hasta bakımı konusunda eğitim almamıştır. Bakım verenlerin \%34,6'sı hasta bakımı ile ilgili eğitim alma konusunda isteklidir. \%71,6'sı hasta bakımı için devletten ya da hasta/hasta yakınından maddi destek almamaktadır (Tablo 1).

Bakım verenlerin \%22,6'sının kan glukoz ölçümü, \%50,6'sının tansiyon takibi, \%34,6'sının ağız bakımı, \%28,1'inin yara bakımı ve \% 18,2 'sinin fizik tedavi egzersizlerini yaptığı saptanmıştır. Bakım verenlerin \%11'i hastaya bakım vermek dışında evde başka görevlerinin olmadığını belirtmiştir. Evde bakıma muhtaç başka birey olmadığını ifade edenlerin oranı $\% 79,1$ 'dir. Bakım verenlerin $\% 46,4$ 'ü, bakım verme sürecinde yardımda bulunan başka birey olmadığını belirtmiştir. Hastaya bakım verenlerin \%22,7'si aile üyelerinden manevi/psikolojik destek aldığını ifade etmiş̧ir. Hasta bakımı verenlerin hasta bakımı yapmaksızın 1 ay içinde kendisine ayırdığ 1 sürenin 0 ile 30 gün arasında değişmekte olup, ortalama 2,24 gün olduğu bulunmuştur $( \pm 4,77)$ (Tablo 1).

Hastaların $\% 45,3$ 'ün de nörobilişsel hastalık ve $\% 20,8$ 'inde dekibüt ülseri olduğu saptanmıştır. Barthel indeksi değerlendirme sonuçlarına göre hastaların \%46,5'i yatağa tam bağımlıdır. Bakım verilen hastaların $\% 51,9$ 'u evde sağlık hizmetini 1 yıldan az süredir almaktadır. Hastaların \% 66,9'unun kullandığı bir tıbbi cihaz vardır. Cihaz kullandığını ifade eden hastaların $\% 32,8$ 'i yürüteç, $\% 26,7$ 'si tekerlekli sandalye, $\% 43,9^{\prime}$ u havalı yatak, $\% 11,2$ 'si oksijen tüpü, $\% 7,8^{\prime}$ i ventilatör/ BPAP ve $\% 6,8$ 'i diğer cihazlardan kullandığını belirtmiştir (Tablo 2).
Tablo 3'de, yaş grupları arasında "cihazların bozulması halinde ne yapılacağını biliyorum" maddesine verilen cevapların değerleri açısından istatistiksel olarak anlamlı farklılık bulunmaktadır (p:0.037; p<0.05) (Tablo 3). Farklllık incelendiğinde; 20-34 yaş grubunun bilgi, beceri düzeyi diğer yaş gruplarından yüksek bulunmuştur $\left(\mathrm{p}_{1}: 0,042 ; \mathrm{p}_{2}: 0,013 ; \mathrm{p}_{3}: 0,045 ; \mathrm{p}<0,05\right)$.

Okur-yazar olmayanların "cihazların nasıl kullanılacağı hakkında yeterli bilgim var" maddesine verilen cevapların değerleri, üniversite mezunlarından istatistiksel olarak anlamlı düzeyde düşük bulunmuştur (p:0,020; p<0,05). İlkokul mezunu ( 5 yıllık eğitim) olanların cevap değerleri, lise ve üniversite mezunlarından düşük bulunmuştur $\left(\mathrm{p}_{1}: 0,005 ; \mathrm{p}_{2}: 0,002 ; \mathrm{p}<0,05\right)$ (Tablo 3 ).

Eğitim durumları arasında "cihazların temizliği ve bakımlarını nasıl yapabileceğimi biliyorum" maddesine verilen cevapların değerleri açısından istatistiksel olarak anlamlı farklılık bulunmaktadır ( $\mathrm{p}: 0,008 ; \mathrm{p}<0,05)$. İlkokul mezunu (5 yıllık eğitim) olanların cevap değerleri, okuryazar olanlardan, lise ve üniversite mezunlarından düşük bulunmuştur $\left(\mathrm{p}_{1}: 0,003 ; \mathrm{p}_{2}: 0,006 ; \mathrm{p}_{3}: 0.004\right.$; $\mathrm{p}<0,05$ ).

Eğitim durumları arasında "hastanın diyeti hakkında bilgim var" maddesine verilen cevapların değerleri açısından istatistiksel olarak anlamlı farklılık bulunmaktadır ( $\mathrm{p}: 0,026 ; \mathrm{p}<0.05)$. Üniversite mezunlarının cevap değerleri, okuryazar olmayanlardan, ilkokul (5 y1llık eğitim) ve ilköğretim (8 yıllık eğitim) mezunlarından yüksek bulunmuştur $\quad\left(\mathrm{p}_{1}: 0,003 ; \quad \mathrm{p}_{2}: 0,013 ; \quad \mathrm{p}_{3}: 0,039\right.$; $\mathrm{p}<0,05$ ).

Eğitim durumları arasında "hastanın fiziksel aktivite ve egzersizleri hakkında bilgim var" maddesine verilen cevapların değerleri açısından istatistiksel olarak anlamlı farklılık bulunmaktadır ( $\mathrm{p}: 0,002 ; \mathrm{p}<0,05)$. Üniversite mezunlarının cevap değerleri, okuz-yazar olmayanlardan, ilkokul (5 yıllık eğitim) ve ilköğretim (8 yıllık eğitim) mezunlarından yüksek bulunmuştur $\left(\mathrm{p}_{1}: 0,000 ; \mathrm{p}_{2}: 0,002 ; \mathrm{p}_{3}: 0,004 ; \mathrm{p}<0,05\right)$.

Eğitim durumları arasında "hastanın kişisel hijyenini sağlamak ve bakımını yapmak için gerekli bilgi ve beceriye sahibim" maddesine verilen cevapların değerleri açısından istatistiksel olarak anlamlı farklılık bulunmaktadır (p:0,043; $\mathrm{p}<0,05$ ). Okur-yazar olmayanların cevap değerleri, okur-yazar olanlardan ve üniversite mezunlarından düşük bulunmuştur $\left(\mathrm{p}_{1}: 0,041 ; \mathrm{p}_{2}: 0,043\right.$; $\mathrm{p}<0,05$ ). İlkokul mezunu (5 yıllık eğitim) olanla- 
rın cevap değerleri ise, okur-yazar olanlardan, lise ve üniversite mezunlarından düşük bulunmuştur $\left(\mathrm{p}_{1}: 0,037 ; \mathrm{p}_{2}: 0,028 ; \mathrm{p}_{3}: 0,029 ; \mathrm{p}<0,05\right)$ (Tablo 3).

Bakım verilen süre açısından "cihazların nasıl kullanılacağı hakkında yeterli bilgim var" maddesine verilen cevapların değerlerinde istatistiksel olarak anlamlı farklılık bulunmaktadır (p:0,043; p<0,05). 7-10 yıl arasında bakım verenlerin cevap değerleri, 1 yıldan az, 1-3 yıl arasinda ve 4-6 yıl arasında bakım verenlerden yüksek bulunmuştur $\left(\mathrm{p}_{1}: 0,004 ; \mathrm{p}_{2}: 0,003 ; \mathrm{p}_{3}: 0,009\right.$; $\mathrm{p}<0,05)$ (Tablo 4)

Daha önce başka bir hastaya bakım verenlerin "cihazların temizliği ve bakımlarını nasıl yapabileceğimi biliyorum" maddesine verdikleri cevapların değerleri, daha önce başka bir hastaya bakım vermeyenlerden düşük bulunmuştur (p:0,031; p<0,05) ( Tablo 5).

\section{TARTIŞMA VE SONUÇ}

Çalışmamızda bakım veren kişilerin demografik özelliklerine bakıldığında literatür ile uyumlu olarak büyük çoğunluğunun kadın $(\% 84,4)$ ve 35 -64 yaş arası $(\% 74,2)$ olduğu görülmüştür. Hastaya bakım verenlerin $\% 63$ 'ü birinci derece aile üyeleri iken, \%14,3 eş ve \%13,3'ü ücretli çalışan olduğunu ifade etmiştir. Ülkemizde ve dünyada yapılan benzer çalışmalarda bu yönde bulgular ortaya koymaktadır. ${ }^{6,7,16-19}$

$\mathrm{Bu}$ çalışmanın sonucu, hastaya bakım verenlerin eğitim seviyelerinin düşük olduğunu hatta \% 6,4'ünün okuryazar olmadığını ve \%6,9'unun okuryazar olmasına rağmen bir diplomasının olmadığını, \%31,6'sının ilkokul mezunu olduğunu göstermiştir. Kalınkaya ve Kalaycı'nın çalışmasında (2017) bakım verenlerin eğitim seviyesi daha düşük bulunmuştur ve katılımcıların yarıdan fazlasının $(\% 54,5)$ sadece okur-yazar veya ilkokul mezunu olduğu tespit edilmiştir. Başka bir çalışmada ise bakım verenlerin \%16,4'ünün okuryazar olmadığ 1 ve $\% 20,1$ 'i bir okuldan mezun değil yalnızca okuryazar olduğu belirtilmiştir. ${ }^{20}$ Yeşiltaş ve Adıgüzel'in çalışmasında ise ilköğretim ve daha düşük eğitim seviyesi olanların oranı $\% 76,1$ bulunmuştur. ${ }^{18}$

Literatür çalışmaları, informal bakım verenlerin büyük çoğunluğunun herhangi bir işte çalışmad1ğını ve zamanın çok büyük bir kısmını hatta bazen tüm gününü hasta bakımı ile uğraşarak evde geçirdiğini göstermektedir. Bizim çalışmamız da bunu destekler nitelikte sonuçlara ulaşılmıştır.
Bakım verenlerin \%86,5'i çalışmadığını ve \% 69,2'si günün nerdeyse tamamını hasta bakımına ayırmakta olduğunu ifade etmiştir. ${ }^{6,19,20}$

Koraltan (2017) gün içinde 6 saat ve üzeri bakım verenlerin oranının katılımcıların \%69,8'ini oluşturduğunu belirtmiştir. Budak'ın çalışmasında katılımcıların \%85,7'si haftanın 7 günü bakım verdiğini belirtmiştir. ${ }^{21}$ Çalışmamızda bakım verenlerin \%20,3'ü bir y1ldan az, \%30,2'si 1-3 y1l aras1 ve \%22,6's1 4-6 y1l arası bakım verdiklerini belirtmişlerdir. Çatak ve arkadaşlarının çalışmasında bakım verme süresi 10'dan daha fazla olanların oranı \%31 bulunmuştur. ${ }^{22}$

Çalışmamızda katılımcıların hasta bakımı yapmaksızın kendine ayırdığı süre ayda ortalama 2,24 gün olarak bulunmuştur. Bunun yanında bakım veren kişilerin çoğunlukla ev içinde temizlik, yemek yapma ya da alışveriş yapma gibi başka sorumluluklar da üstlendikleri saptanmıştır. Çalışmamızda başka bir sorumluluğu olmadığını belirten katılımcıların oranı \%11 olarak bulunmuştur.

Katılımcıların yarısından biraz fazlası $(\% 53,6)$ hastanın bakımı için kendisine yardımcı olan başka bir kişinin varlığını ifade etmiştir. Kalınkaya ve Kalaycı'nın çalışma sonucu da bizimki ile benzer şekildedir; bakım verenlerin yarıdan çoğu aile üyelerinden, yakınlarından ve bakıcılardan destek aldığını bildirmiştir. ${ }^{6}$ Koraltan'ın çalışmasında ${ }^{16}$ bakım için yardım aldığını belirten katılımcı oranı bizim çalışmamızdan daha yüksektir $(\% 61,6)$. Budak, çalışmasında görüştüğü bakım verenlerin \%3,6'sının az/hiç yük, \% 39,3'ünün orta derecede yük, \%39,3'ünün ileri derecede yük ve \%17,9'unun aşırı derecede yük hissettiği tespit edilmiştir. ${ }^{21}$ Bir diğer çalışmada ise bakım verenlerin \%63,4'ü kendini yardımsız ve \%53'ü umutsuz hissettiğini belirtmiştir. Bakım verenin bakım görevini paylaştığı bir kişi olması durumunda bakım yükünü daha az hissettiğini ifade etmiştir. ${ }^{23}$ Bakım yükünün hafifletilmesi için hastaya bakım verenlerin hem fiziksel hem de manevi yönden desteklenmesi gerekmektedir. Ancak bizim çalışmamızda görüldüğü üzere hiç manevi destek almadığını belirtenler oldukça yüksek seviyededir $(\% 65,9)$. Manevi destek alanlar ise çoğunlukla aile yakınlarından (\% 22,7) destek aldıklarını ifade etmiştir. Buna karşılık bir dernekten manevi destek alanlar katılımc1ların yalnızca $\% 0,3$ 'üdür.

Çalışmamızda hastaların \%45,3'ünde nörobilişsel hastalık tanısı bulunmaktadır. Hastaların \% 
46,5'i Barthel indeksine göre tam bağımlıdır ve $\% 20,8$ 'inde dekübit ülseri bulunmaktadır. Akdemir ve arkadaşlarının çalışmasında, hastaların \% 76,3'ünün hemiplejisi, \%23,7'sinin ise hemiparazisi mevcut olduğu ve yatağa bağımlılık durumu nedeniyle bası yarası $(\% 28,9)$ ve çeşitli enfeksiyonların $(\% 36,8)$ görülme oranlarının yüksek olduğu ifade edilmiştir. Araştırmacılar, hastaya bakım verenlerin eğitim ile desteklenmesinin hastanın sağlık durumuna olumlu katkı yapacağını belirtmiştir. ${ }^{24}$ Farklı çalışmalar da evde sağlık hizmeti alan hastalarında bası yarası görülme oranının yüksek olduğunu ortaya koymaktadır. Çayır ve arkadaşları bu oranı \%42,1, Aktürk ve arkadaşları (2010) \%23,8 ve Hisar ve Erdoğdu (2014) \%27,7 şeklinde bulmuştur. ${ }^{17,25,26}$ Çalışmamızın sonuçlarına göre, hastaların \% 66,9 'u en az bir cihaz kullanmaktadır ve bu cihazların \%32,8'i yürüteç, \%26,7'si tekerlekli sandalye, $\% 43,9$ 'u havalı yatak, $\% 11,2$ 'si oksijen tüpü, \%7,8'i ventilatör/BPAP ve \%6,8'i diğer cihazlardır. Yapılan başka bir çalışmada yaşlıların \%18,5'i günlük yaşam aktivitelerini gerçekleştirmek için herhangi bir cihaz kullanmıyor iken, \%32,4'ünün baston, yürüteç, koltuk değneği; \%21,3'ünün tekerlekli sandalye kullandığg tespit edilmiştir. $^{22}$

Yapılan çalışmalar, yaşlı bakımı konusunda bir eğitim almadığını ve kendini yetersiz hissettiğini ifade eden bakım verenlerin azımsanamayacak oranda olduğunu göstermektedir. ${ }^{6}$ Bulgularımıza göre de katılımcıların \%85'i, bakım konusunda bir eğitim almamıştır ve eğitim almak isteyenlerin oranı \%34,6'dır. Yapılan bir çalışmada, bakım verenlerin $\% 78^{\prime} i$ en az bir konu ile ilgili eğitim almak istediğini belirtmiştir. Eğitim almak istenilen konular arasında; başa çıkma stratejileri $(\% 61,3)$, duygusal destek $(\% 53,5)$, semptomların takibi $(\% 48,5)$ ve sağlık sigortası ile ilgili konular $(\% 45,5)$ yer almaktadır. ${ }^{27}$ Benzer bir çalışmada, katılımcıların \%77'sinin en az bir konuyla ilgili yardıma veya bilgiye ihtiyaç duyduğu tespit edilmiştir. Güvenli bakım (\%37), stres yönetimi (\%34), bakım gereksinimi olan kişiye anlamlı faaliyetler sağlamak (\%34) ve kendileri için zaman bulmak (\%32) en sık bildirilen bilgi ihtiyaçları olarak gösterilmiştir. ${ }^{28}$ Rice ve arkadaşlarının çalışmasında bakım verenlerin yarısı (\%50) bakım verme ile ilgili bilgi eksiği olduğunu söylemiştir. ${ }^{29}$

Çalışmamızda anket uygulanan bakım verenlerin çoğunluğu $(\% 77,3)$ daha önce başka hastaya bakım vermediğini ve yarısı $(\% 50,5)$ hastaya 3 yıldan kısa bir süredir bakım verdiğini ifade etmiştir. Evde bakım verilen hastaların bağımlılık durumları, mevcut hastalıklarına yönelik bakım ve takipler, kullandığı cihazlar, ilaçlar, diyeti gibi hususlar göz önünde tutulduğunda, bakım verenin bilgi ve beceri sahibi olabilmesi için destekleme ihtiyacı olduğu açıktır. Çalışmamızda bakım verenlerin hastanın diyeti ve ilaçlarının kullanımı konularında yeterince bilgi sahibi olduğu buna karşılık en çok tıbbi cihazların kullanımı, arızalanması durumunda ne yapacağı ve temizlik bakımı ile ilgili bilgi eksikliği olduğu görülmektedir. 20-34 yaş arası bakım verenlerin ve eğitim seviyesi daha yüksek olanların bilgi durumları diğer gruplara göre daha yüksek bulunmuştur.

Aile üyelerinden biri, arkadaşlar veya komşular gibi informal bakım verenler ya da sağlık profesyonelleri gibi formal bakım verenler evde sağlık hizmetleri süreci içinde yer almaktadır. Bakım verenlerin bu çeşitliliği bakım verme sürecinde farklılıklara sebep olmaktadır. Bu sorunlardan birisi de bakım verenlerin bilgi ve beceri seviyesinin aynı olmamasıdır. Bakım veren kişilerin bakım verme konusundaki bilgileri, bakım alan kişilerin yaşam sürelerini etkilemektedir. Bilgi düzeyinin düşük olması bakım alan kişinin yaşam süresinin kısalmasına neden olmaktadır. ${ }^{30}$ Bakımın standartlaştırılması için bakım veren sağlık çalışanlarına alana özgü eğitimler verilmelidir. ${ }^{13}$ Ancak evde sağlık hizmetlerinde informal bakım verenlerin önemli payı unutulmamalı ve bu kişilerin bilgi ve becerilerini artırmaya yönelik destek sağlanmalıdır.

Hasta yakınlarının bilgi ve beceri düzeyinin yükseltilmesi, aynı zamanda hastanın alacağı bakımın kalitesini de yükseltecek ve hastayı olumsuz sağlık koşullarından koruyacaktır. Bu nedenle eğitim ile hasta yakınlarının bilgi ve becerilerinin yükseltilmesi önemli bir husustur. Ancak bu eğitimlerin planlaması ve uygulaması, hastaya bakım verenin yaşı, eğitim durumu ve talep ettiği konular ya da kendini eksik hissettiği alanlar gözetilerek yapılmalıdır. Hedef kitleye yönelik yazılı basılı materyallerin yanı sıra uygulamal, görsel, işitsel ya da farklı tekniklerde eğitimler hazırlanmalıdır.

Ayrıca hasta yakınlarına manevi destek ve kendine kaliteli zaman ayırmasına imkan tanınması oldukça önemlidir. Kişilerin maddi ve manevi 
açıdan güçlendirilmesi için ilgili kurum ve kuruluşlar ile işbirliği yapılması gerekmektedir. Sivil toplum kuruluşlarının ve çeşitli kurum/ kuruluşların bu yönde desteklerini artırmalarının önemli olduğu düşünülmektedir.

Etik Komite Onayı: Çalışma öncesi S.B.Ü. Fatih Sultan Mehmet Eğitim ve Araştırma Hastanesi Etik Kurulu'ndan onay alınmıştır (Tarih: 28/03/2019, karar no: 2019/6).

Çıkar Çatışması: Yazarlar çıkar çatışması bildirmemişlerdir.

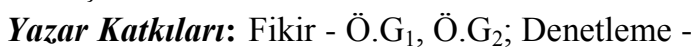
Y.S; Veri toplanması ve/veya işlemesi - Ö.G , $_{1}$ Ö.G $\mathrm{G}_{2}$; Analiz ve/veya yorum - Ö.G $\mathrm{G}_{2}$, Y.S; Yazıyı yazan - Ö.G . $_{1}$

Hakem dĕgerlendirmesi: Dış bağımsız.

\section{KAYNAKLAR}

1. OECD. Health at a Glance 2015: OECD Indicators. Paris: OECD Publishing; 2015.https:// www.oecd-ilibrary.org/social-issuesmigration-health/health-at-a-glance2015_health_glance-2015-en. Erişim tarihi 10 Ocak 2020

2. TÜİK. Hayat Tabloları. http:// www.tuik.gov.tr/PreHaberBultenleri.do? $\mathrm{id}=24644$. Erişim tarihi 30 Mart 2019.

3. TÜİK. İstatistiklerle Yaşlılar, 2018. http:// www.tuik.gov.tr/PreHaberBultenleri.do? $\mathrm{id}=30699$. Erişim tarihi 10 Ocak 2020.

4. WHO. Technical Report Series 898. HomeBased Long-Term Care. Geneva: 2000. https://apps.who.int/iris/bitstream/ handle/10665/42343/

WHO_TRS_898.pdf;sequence=1 Erişim tarihi 30 Mart 2019.

5. Sağlık Bakanlığı. Sağlık Bakanlığınca Sunulan Evde Sağlık Hizmetlerinin Uygulama Usul ve Esasları Hakkında Yönerge. ttps:// dosyasb.saglik.gov.tr/

Eklenti/1352,yonergedocx.docx?0. Erişim tarihi 30 Mart 2019.

6. Kalınkaya V, Kalaycı I. Yaşlıya evde bakım hizmeti veren bireylerde yaşam doyumu, bakım yükü ve tükenmişlik. Yaşlı Sorunları Araştırma Dergisi 2007;10(2):19-39.

7. Zaybak A, Güneş Ü, Günay İsmailoğlu E, Ülker E. Yatağa bağımlı hastalara bakım veren bireylerin bakım yüklerinin belirlenmesi. Anadolu Hemşirelik ve Sağlık Bilimleri Dergisi. 2012;15(1):48-54.

8. İncesu E, Tombul C, Arkan M, Babuçcu H.
Evde sağlık hizmetleri erişebilirlik: Konya Seydişehir Devlet Hastanesi evde sağlık hizmetleri birimi örneği. Tıbbi Sosyal Hizmet Dergisi. 2014;(4):18-25.

9. Yılmaz M, Şara E. Yaşlılık ve evde sağlık hizmetinde finansman. Sağllk Akademisyenleri Dergisi. 2014;1(2):117-127.

10. Kurt ME, Çemberlitaş İ, Şen MA. Evde sağlik hizmetleri birimi tarafindan sunulan hizmetlerin sosyal devlet olma ilkesi açısından değerlendirilmesi. Dicle Üniversitesi İktisadi ve İdari Bilimler Dergisi. 2019;9(18):307319.

11. Özer Ö, Şantaş F. Kamunun sunduğu evde bakım hizmetleri ve finansmanı. Acıbadem Üniversitesi Sağlık Bilimleri Dergisi. 2012;3 (2):96-103.

12. Yılmaz M, Sametoğlu F, Akmeşe G, ve ark. Sağlık hizmetinin alternatif bir sunum şekli olarak evde hasta bakımı. İstanbul Tıp DergIstanbulMed. 2010;11(3):125-132.

13. National Research Council. Health care comes home: the human factors. Washington DC: The National Academies Press; 2011.

14. OECD. Health at a Glance 2017: OECD Indicators. http://dx.doi.org/10.1787/ health_glance-2017-en. Erişim tarihi 15 Ağustos 2019.

15. Taşdelen P, Ateş M. Evde bakım gerektiren hastaların bakım gereksinimleri ile bakım verenlerin yükünün değerlendirilmesi. Hemşirelikte Eğitim ve Araştırma Dergisi. 2012;9 (3):22-29.

16. Koraltan A. Eve bağımlı hastalara bakım verenlerin genel sağlık algısı ile kişilik özellikleri arasındaki ilişkinin araştırılması. Doğuş Üniversitesi Sosyal Bilimler Enstitüsü Psikoloji Anabilim Dalı Klinik Psikoloji Bilim Dalı, Yüksek Lisans Tezi. İstanbul, Türkiye. 2017.

17. Çayır Y, Avşar ÜZ, Avşar Ü, Cansever Z, Khan AS. Evde sağlık hizmetleri alan hastaların özellikleri ve bakım verenlerin beklentileri. Konuralp Tip Dergisi. 2013;5(3):9-12.

18. Yeşiltaş A, Adıgüzel O. Evde sağlık hizmetlerinde hasta yakınlarının memnuniyeti. Çankırı Karatekin Üniversitesi Sosyal Bilimler Enstitüsü Dergisi. 2016;7(1):863-880.

19. Chen MC, Kao CW, Chiu YL, ve ark. Effects of home-based long-term care services on caregiver health according to age. Health and Quality of Life Outcomes. 2017;15:208.

20.Erdoğan B. Evde bakım hizmeti alan özürlü 
bireye sahip ailelerin sosyo-ekonomik durumlarının incelenerek, umutsuzluk ve yaşam doyum düzeylerinin belirlenmesi. Selçuk Üniversitesi Sağlık Bilimleri Enstitüsü, Yüksek Lisans Tezi. Konya, Türkiye. 2013.

21. Budak S. Palyatif bakım alan peg (perkütan endoskopik gastrostomi) ve ng (nazogastrik)'li hastalara bakım verenlerin bakım yükü ve yaşam kalitesinin incelenmesi. Balıkesir Üniversitesi. Sağlık Bilimleri Enstitüsü Hemşirelik Anabilim Dalı, Yüksek Lisans Tezi. Balıkesir, Türkiye. 2019.

22. Çatak B, Öner C, Kılınç AS, Sütlü S, Şenbayram S. Yașlilara evde bakım verenlerde ruhsal hastalık belirtisi sıklığı ve etkileyen faktörler. Kafkas J MedSci. 2012;2(3):105-108.

23. Erinmez G, Aydın Avcı İ. Radyoterapi alan hastaların bakım verenlerinin yaşadıkları güçlükler ve bakım yükleri. 4th International Symposium on Innovative Approaches in Healthand Sports Sciences. 22-24 Kasim 2019, Samsun/Türkiye.

24. Akdemir N, Bostanoğlu H, Yurtsever S, Kutlutürkan S, Kapucu S, Canlı Özer Z. Yatağa bağımlı hastaların evde yaşadıkları sağlık sorunlarına yönelik evde bakım hizmet gereksinimleri. Dicle Tip Dergisi. 2011;38(1):5765.

25. Akturk AŞ, Atmaca E, Zengin S, Bayramgürler D. Kocaeli ilinde evde bakım hizmeti alan hastalarda bası ülserlerinin prevalansı ve klinik özellikleri. Turkderm. 2010;44:128-131.

26. Hisar KM, Erdoğdu H. Evde sağllk hizmeti alanlarda yaşam kalitesi durumu ve etkileyen faktörlerin belirlenmesi. Genel Tip Derg. 2014;24:138-142.

27. Wilkins VM, Bruce ML, Sirey JA. Caregiving tasks and training interests of family caregivers of medically ill home bound older adults. Journal of Aging and Health. 2010;21 (3):528-542.

28. National Alliance for Caregiving \& American Association of Retired Persons. Caregiving in the U.S. http://www.caregiving.org/data/ Caregiving_in_the_US_2009_full_report.pdf. Erişim tarihi 15 Mayıs 2020.

29. Rice DB, Cañedo-Ayala M, Carboni-Jiménez A, ve ark. Challenges and support service preferences of informal caregivers of people with systemic sclerosis: a cross-sectional survey. Disability and Rehabilitation. 2020;42
(16):2304-2310.

doi.org/10.1080/09638288.2018.1557268.

30. Subaşı N, Öztek Z. Türkiye'de karşılanamayan bir gereksinim: evde bakım hizmeti. TSK Koruyucu Hekimlik Bülteni. 2006;5(1):1931. 
Tablo 1. Bakım veren kişiye ait özellikler in dağılımları.

\begin{tabular}{|c|c|c|c|}
\hline & & Sayı & $\%$ \\
\hline \multirow[t]{4}{*}{ Yaş $(n=616)$} & 20 yaş ve altı & 8 & 1,3 \\
\hline & $20-34$ & 37 & 6 \\
\hline & $35-64$ & 457 & 74,2 \\
\hline & 65 ve üstü & 114 & 18,5 \\
\hline \multirow[t]{2}{*}{ Cinsiyet $(\mathrm{n}=616)$} & Kadın & 520 & 84,4 \\
\hline & Erkek & 96 & 15,6 \\
\hline \multirow[t]{4}{*}{ Hasta ile yakınlığ $(\mathrm{n}=610)$} & Eş & 87 & 14,3 \\
\hline & Birinci derece akraba (anne-baba-kardeş-çocuk) & 384 & 63 \\
\hline & İkinci derece akraba & 58 & 9,5 \\
\hline & Ücretli çalışan & 81 & 13,3 \\
\hline \multirow[t]{6}{*}{ Eğitim $(n=610)$} & Okur-yazar değil & 39 & 6,4 \\
\hline & Okur-yazar & 42 & 6,9 \\
\hline & İlkokul mezunu (5 yıllık eğitim) & 193 & 31,6 \\
\hline & İlköğretim okulu mezunu ( 8 yıllık eğitim) & 89 & 14,6 \\
\hline & Lise & 126 & 20,7 \\
\hline & Üniversite & 121 & 19,8 \\
\hline \multirow{3}{*}{$\begin{array}{l}\text { Çalışma (hasta bakımı dışında çalı- } \\
\text { ş1lan bir iş olup olmaması) }(n=614)\end{array}$} & Çalışmıyor & 531 & 86,5 \\
\hline & Tam zamanlı çalışıyor & 57 & 9,3 \\
\hline & Kısmi zamanlı çalışıyor & 26 & 4,2 \\
\hline \multirow{4}{*}{$\begin{array}{l}\text { Hasta ve bakım verenden başka } \\
\text { evde yaşayan kişi sayısı }(n=616)\end{array}$} & Yok & 87 & 14,1 \\
\hline & 1-3 kişi & 388 & 63 \\
\hline & 4-6 kişi & 137 & 22,2 \\
\hline & 7 kişi ve üstü & 4 & 0,6 \\
\hline \multirow{6}{*}{$\begin{array}{l}\text { Bakım verenin hastaya bakım verdi- } \\
\text { gi süre }(n=602)\end{array}$} & 1 y1ldan az & 122 & 20,3 \\
\hline & $1-3$ y1l & 182 & 30,2 \\
\hline & $4-6$ yil & 136 & 22,6 \\
\hline & $7-10$ y1l & 79 & 13,1 \\
\hline & $10-15 \mathrm{y} 11$ & 39 & 6,5 \\
\hline & 16 y1l ve üstü & 44 & 7,3 \\
\hline \multirow{3}{*}{$\begin{array}{l}\text { Gün içinde hastanın bakımının pri- } \\
\text { mer olarak üstlenildiği süre }(n=614)\end{array}$} & $1-8$ saat aras1 & 65 & 10,6 \\
\hline & 9-16 saat aras1 & 124 & 20,2 \\
\hline & $17-24$ saat aras1 & 425 & 69,2 \\
\hline \multirow{2}{*}{$\begin{array}{l}\text { Daha önce başka bir hastaya bakım } \\
\text { verme }(n=607)\end{array}$} & Hayır & 469 & 77,3 \\
\hline & Evet & 138 & 22,7 \\
\hline \multirow{5}{*}{$\begin{array}{l}\text { Hasta bakımı konusunda eğitim } \\
(\mathrm{n}=612)\end{array}$} & Eğitim almadı & 520 & 85 \\
\hline & Hastanede sağlık çalışanları tarafından & 53 & 8,6 \\
\hline & Evde sağllk hizmetleri ekibi tarafından & 20 & 3,3 \\
\hline & Bir kurs programında eğitim/sertifikam & 7 & 1,1 \\
\hline & Sağlık ile ilgili bir okul/bölümden mezun oldum & 12 & 2 \\
\hline \multirow{2}{*}{$\begin{array}{l}\text { Hasta bakımı ile ilgili eğitim alma } \\
\text { isteği }(\mathrm{n}=593)\end{array}$} & Evet & 205 & 34,6 \\
\hline & Hayır & 388 & 65,4 \\
\hline
\end{tabular}

\section{Devamı diğer sayfada}


Tablo 1. Bakım veren kişiye ait özellikler in dağılımları (DEVAM)

\begin{tabular}{|c|c|c|c|}
\hline & & Sayı & $\%$ \\
\hline \multirow[t]{3}{*}{ Maddi destek $(\mathrm{n}=580)$} & Hayır & 441 & 71,6 \\
\hline & Devletten maddi yardım & 81 & 13,1 \\
\hline & Hasta/hasta yakınından maddi yardım & 58 & 9,4 \\
\hline \multirow[t]{5}{*}{ Hastaya verilen rutin bakım işlemi } & Kan şekeri ölçümü & 139 & 22,6 \\
\hline & Tansiyon takibi & 312 & 50,6 \\
\hline & Ağız bakımı & 213 & 34,6 \\
\hline & Yara bakımı & 173 & 28,1 \\
\hline & Fizik tedavi & 112 & 18,2 \\
\hline \multirow{5}{*}{$\begin{array}{l}\text { Evdeki diğer görev ve sorumluluk- } \\
\text { lar }\end{array}$} & Başka görev yok & 68 & 11 \\
\hline & Yemek yapmak & 484 & 78,6 \\
\hline & Evin genel temizliği & 490 & 79,5 \\
\hline & Alış-veriş & 404 & 65,6 \\
\hline & Diğer & 11 & 1,8 \\
\hline \multirow[t]{5}{*}{ Evde bakıma muhtaç başka biri } & Yok & 487 & 79,1 \\
\hline & $0-6$ yaş arası çocuk & 39 & 6,3 \\
\hline & 6-12 yaş arası çocuk bakımı & 22 & 3,6 \\
\hline & Yaşlı var & 43 & 7 \\
\hline & Hasta var & 21 & 3,4 \\
\hline \multirow[t]{2}{*}{ Bakıma yardımcı başka biri } & Hayır & 286 & 46,4 \\
\hline & Evet & 330 & 53,6 \\
\hline \multirow{7}{*}{$\begin{array}{l}\text { Manevi/psikolojik destek alınan } \\
\text { kişi ve kuruluş }\end{array}$} & Yok & 406 & 65,9 \\
\hline & Aile üyesi & 140 & 22,7 \\
\hline & Arkadaş & 30 & 4,9 \\
\hline & Dernek & 2 & 0,3 \\
\hline & Eğitim kuruluşu & 0 & 0 \\
\hline & Dini kuruluş & 0 & 0 \\
\hline & Diğer & 11 & 1,8 \\
\hline $\begin{array}{l}\text { Hasta bakımı yapmaksızın } 1 \text { ay } \\
\text { içinde kendisine ayrılan süre (gün) } \\
\text { Min-Mak, (Ort } \pm \text { SS); [medyan] }\end{array}$ & \multicolumn{3}{|l|}{$0-30(2,24 \pm 4,77) ;[2)]$} \\
\hline
\end{tabular}


Tablo 2. Bakım verilen hastaya ait özellikler in dağılımları.

\begin{tabular}{|c|c|c|c|}
\hline & & Sayı & $\%$ \\
\hline \multirow[t]{3}{*}{ Nörobilişsel hastalık (n=616) } & Cevap verilmedi & 227 & 36,9 \\
\hline & Hayır & 110 & 17,9 \\
\hline & Evet & 279 & 45,3 \\
\hline \multirow[t]{2}{*}{ Dekibüt ülseri $(n=606)$} & Hayır & 480 & 79,2 \\
\hline & Evet & 126 & 20,8 \\
\hline \multirow{5}{*}{$\begin{array}{l}\text { Yatağa bağımlılık durumu (Barthel indeksi } \\
\text { sonucu) }(\mathrm{n}=591)\end{array}$} & Tam bağımlı & 275 & 46,5 \\
\hline & İleri derece bağımlı & 137 & 23,2 \\
\hline & Orta derece bağımlı & 138 & 23,4 \\
\hline & Hafif derece bağımlı & 35 & 5,9 \\
\hline & Tam bağımsız & 6 & 1 \\
\hline \multirow[t]{5}{*}{ Evde sağlık hizmeti aldığı süre (n=601) } & 1 y1ldan az & 312 & 51,9 \\
\hline & $1-3$ yil & 210 & 34,9 \\
\hline & $4-6$ y1l & 69 & 11,5 \\
\hline & $7-10$ y1l & 9 & 1,5 \\
\hline & 16 y1l ve üstü & 1 & 0,2 \\
\hline \multirow[t]{3}{*}{ Kullandığı Cihaz Durumu $(\mathrm{n}=616)$} & Yok & 170 & 27,6 \\
\hline & Var & 412 & 66,9 \\
\hline & Belirtilmemiş & 34 & 5,5 \\
\hline \multirow[t]{6}{*}{ Kullanılan Cihaz $(\mathrm{n}=412)$} & Yürüteç & 135 & 32,8 \\
\hline & Tekerlekli sandalye & 110 & 26,7 \\
\hline & Havalı yatak & 181 & 43,9 \\
\hline & Oksijen tüpü & 46 & 11,2 \\
\hline & Ventilator/BPAP & 32 & 7,8 \\
\hline & Diğer & 28 & 6,8 \\
\hline
\end{tabular}




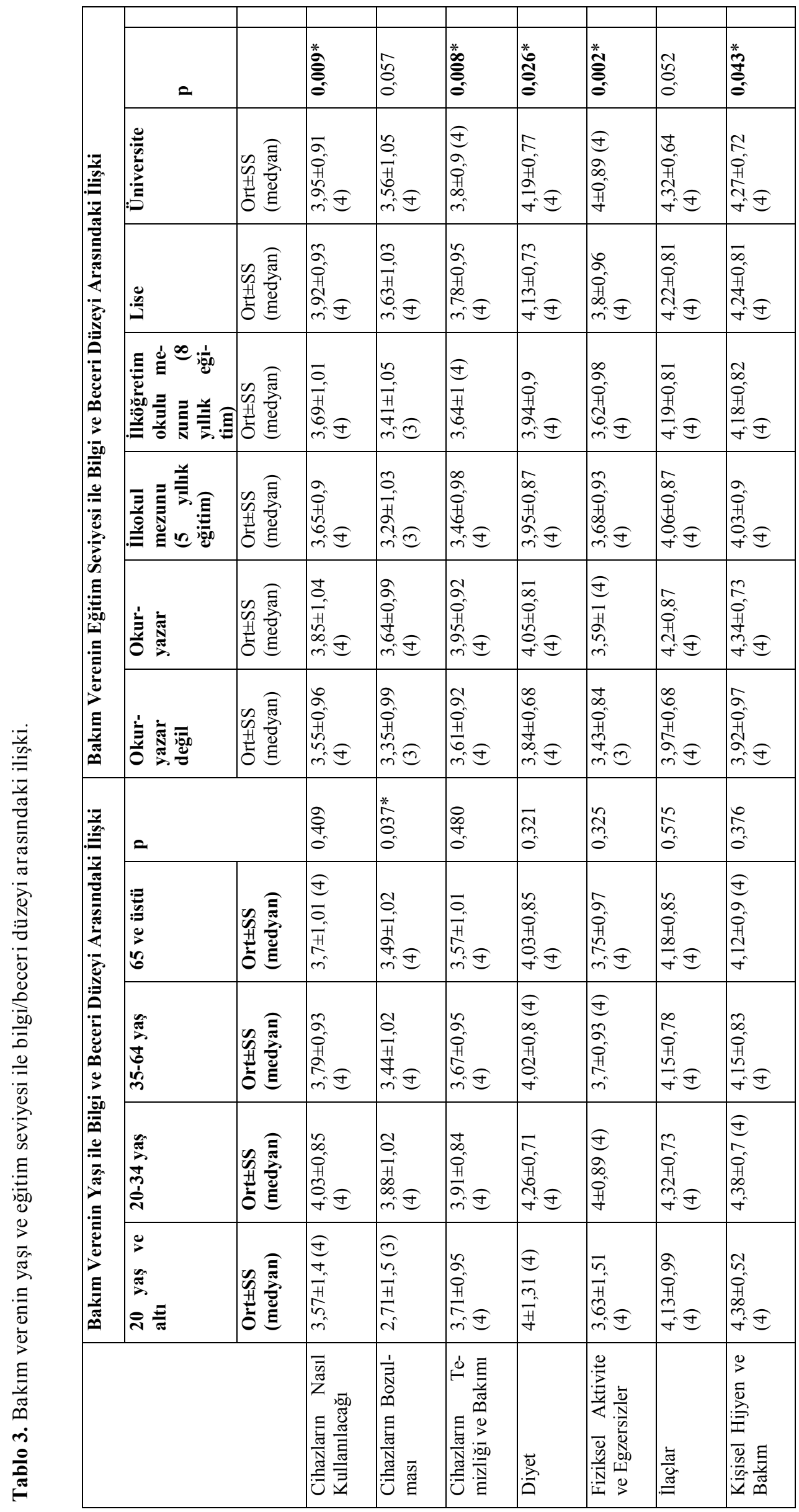


Tablo 4. Bakım verenin hastaya bakım verdiği süre ve bilgi/beceri düzeyi arasındaki ilişki.

\begin{tabular}{|c|c|c|c|c|c|c|c|}
\hline & 1 yıldan az & $1-3$ y1l & 4-6 y1l & $7-10$ y1l & $10-15$ y1l & $\begin{array}{l}16 \text { y1l ve } \\
\text { üstü }\end{array}$ & \multirow[b]{2}{*}{$\mathrm{p}$} \\
\hline & $\begin{array}{l}\text { Ort } \pm \text { SS } \\
\text { (medyan) }\end{array}$ & $\begin{array}{l}\text { Ort } \pm \text { SS } \\
\text { (medyan) }\end{array}$ & $\begin{array}{l}\text { Ort } \pm \text { SS } \\
\text { (medyan) }\end{array}$ & $\begin{array}{l}\text { Ort } \pm \text { SS } \\
\text { (medyan) }\end{array}$ & $\begin{array}{l}\text { Ort } \pm \text { SS } \\
\text { (medyan) }\end{array}$ & $\begin{array}{l}\text { Ort } \pm \text { SS } \\
\text { (medyan) }\end{array}$ & \\
\hline $\begin{array}{ll}\text { Cihazların } & \text { Nasıl } \\
\text { Kullanılacağ1 } & \end{array}$ & $\begin{array}{l}3,72 \pm 0,91 \\
(4)\end{array}$ & $\begin{array}{l}3,71 \pm 0,96 \\
\text { (4) }\end{array}$ & $\begin{array}{l}3,7 \pm 1,03 \\
(4)\end{array}$ & $\begin{array}{l}4,1 \pm 0,79 \\
(4)\end{array}$ & $\begin{array}{l}3,97 \pm 0,85 \\
\text { (4) }\end{array}$ & $\begin{array}{l}3,83 \pm 0,94 \\
(4)\end{array}$ & $0,043^{*}$ \\
\hline $\begin{array}{l}\text { Cihazların Bozul- } \\
\text { mas1 }\end{array}$ & $\begin{array}{l}3,42 \pm 1,05 \\
\text { (4) }\end{array}$ & $\begin{array}{l}3,46 \pm 0,98 \\
\text { (4) }\end{array}$ & $\begin{array}{l}3,48 \pm 1,02 \\
\text { (4) }\end{array}$ & $\begin{array}{l}3,53 \pm 1,15 \\
\text { (4) }\end{array}$ & $\begin{array}{l}3,43 \pm 1,14 \\
(4)\end{array}$ & $\begin{array}{l}3,5 \pm 1,04 \\
(4)\end{array}$ & 0,984 \\
\hline $\begin{array}{l}\text { Cihazların Temizli- } \\
\text { ği ve Bakımı }\end{array}$ & $\begin{array}{l}3,69 \pm 0,87 \\
\text { (4) }\end{array}$ & $\begin{array}{l}3,59 \pm 0,97 \\
\text { (4) }\end{array}$ & $\begin{array}{l}3,66 \pm 1,01 \\
\text { (4) }\end{array}$ & $\begin{array}{l}3,8 \pm 1,02 \\
(4)\end{array}$ & $\begin{array}{l}3,94 \pm 0,77 \\
\text { (4) }\end{array}$ & $\begin{array}{l}3,57 \pm 0,97 \\
(4)\end{array}$ & 0,310 \\
\hline Diyet & $\begin{array}{l}3,95 \pm 0,76 \\
\text { (4) }\end{array}$ & $\begin{array}{l}4,09 \pm 0,81 \\
\text { (4) }\end{array}$ & $\begin{array}{l}3,98 \pm 0,87 \\
\text { (4) }\end{array}$ & $\begin{array}{l}4,08 \pm 0,9 \\
(4)\end{array}$ & $\begin{array}{l}4,23 \pm 0,73 \\
\text { (4) }\end{array}$ & $4 \pm 0,78$ (4) & 0,246 \\
\hline $\begin{array}{l}\text { Fiziksel Aktivite ve } \\
\text { Egzersiz }\end{array}$ & $\begin{array}{l}3,68 \pm 0,95 \\
\text { (4) }\end{array}$ & $\begin{array}{l}3,69 \pm 0,96 \\
\text { (4) }\end{array}$ & $\begin{array}{l}3,74 \pm 0,97 \\
\text { (4) }\end{array}$ & $\begin{array}{l}3,87 \pm 0,97 \\
\text { (4) }\end{array}$ & $\begin{array}{l}3,86 \pm 0,8 \\
(4)\end{array}$ & $\begin{array}{l}3,8 \pm 0,85 \\
\text { (4) }\end{array}$ & 0,676 \\
\hline İlaçlar & $\begin{array}{l}4,14 \pm 0,72 \\
\text { (4) }\end{array}$ & $\begin{array}{l}4,12 \pm 0,86 \\
\text { (4) }\end{array}$ & $\begin{array}{l}4,19 \pm 0,78 \\
\text { (4) }\end{array}$ & $\begin{array}{l}4,2 \pm 0,84 \\
(4)\end{array}$ & $\begin{array}{l}4,43 \pm 0,56 \\
(4)\end{array}$ & $\begin{array}{l}4,16 \pm 0,81 \\
\text { (4) }\end{array}$ & 0,450 \\
\hline $\begin{array}{l}\text { Kişisel Hijyen ve } \\
\text { Bakım }\end{array}$ & $\begin{array}{l}4,14 \pm 0,73 \\
\text { (4) }\end{array}$ & $\begin{array}{l}4,14 \pm 0,88 \\
\text { (4) }\end{array}$ & $\begin{array}{l}4,13 \pm 0,87 \\
\text { (4) }\end{array}$ & $\begin{array}{l}4,16 \pm 0,88 \\
\text { (4) }\end{array}$ & $\begin{array}{l}4,25 \pm 0,84 \\
\text { (4) }\end{array}$ & $\begin{array}{l}4,32 \pm 0,64 \\
(4)\end{array}$ & 0,812 \\
\hline
\end{tabular}

Kruskal Wallis Test; * $p<0.05$ 
Tablo 5. Bakım verenin daha önce başka bir hastaya bakım verip vermeme durumu ve bilgi/beceri düzeyi arasındaki ilişki.

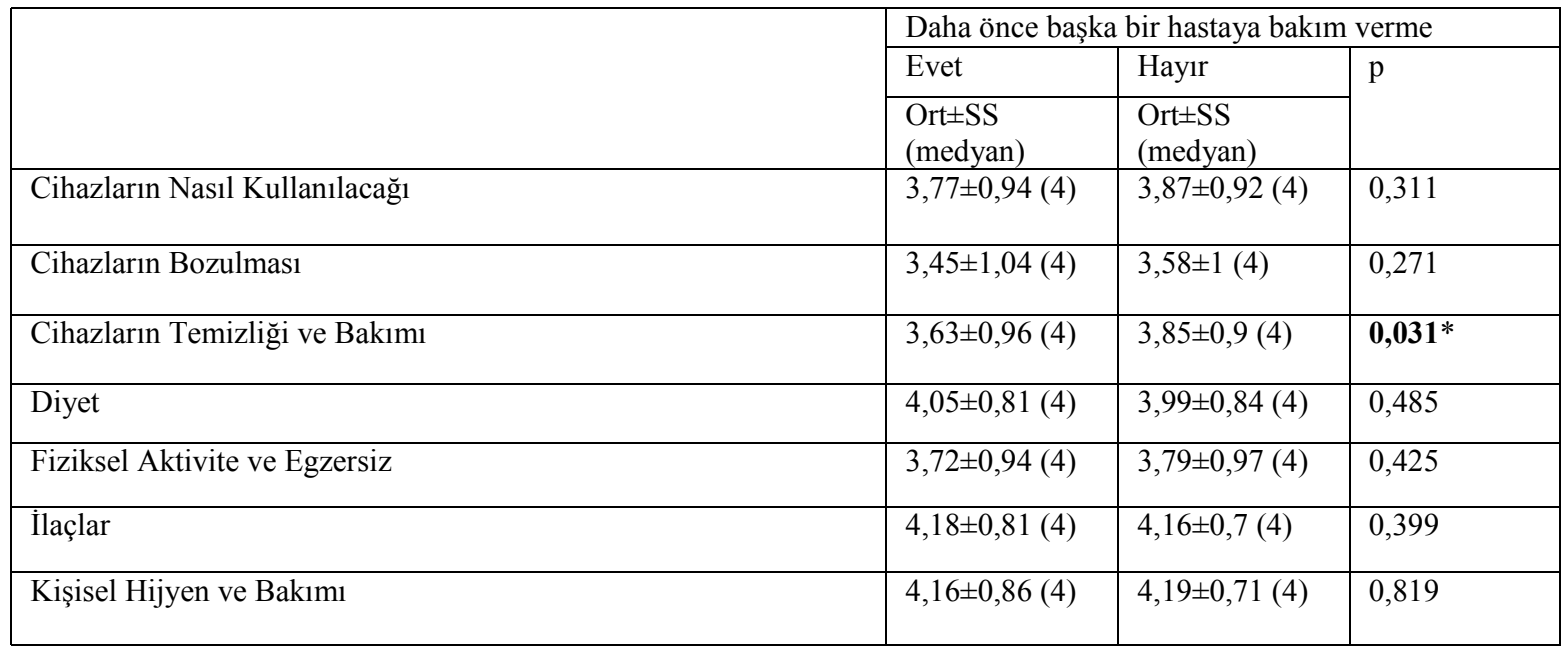

Mann Whitney U Test; *p<0,05 